\title{
Product Market Regulation and Macroeconomic Performance: \\ A Review of Cross-Country Evidence
}

By

\author{
Fabio Schiantarelli
}

(Boston College and IZA)

Revised, August 4, 2008

\begin{abstract}
The main purpose of this paper is to provide a critical overview of the recent empirical contributions that use cross-country data to study the effect of product market regulation and reform on a country's macroeconomic performance. After a review of the theoretical literature and of relevant micro-econometric evidence, the paper discusses the main data and methodological issues related to empirical work on this topic. It then critically evaluates the cross-country evidence on the effect of product market regulation on markups, firm dynamics, investment, employment, innovation, productivity and output growth. A summary of what we learn from the econometric results concludes the paper.
\end{abstract}

JEL Classification: D24, K20, L10, L51,O31,O40,O57

Key-Words: Regulation, Product Market, Performance, Productivity, Innovation, Growth

Acknowledgments: This research has been supported by the World Bank Latin American Regional Studies Program. I would like to thank F. Giavazzi, R. Griffith, N. Loayza, G. Nicoletti, A. Sembenelli, and L. Serven for useful conversations and comments. The views expressed here are those of the author and do not necessarily represent those of the World Bank, its Board of Directors, or the countries they represent. 


\section{Introduction}

During the last fifteen years many countries at different levels of development have introduced significant regulatory reforms of the product market, of factor markets, and of the financial sector. Most of the empirical literature on the effect of product and factor markets regulation (or regulatory reform) has focused on the labour market. Much of it has focused on explaining the different performance of continental European countries versus the United States and other OECD countries or the effect of relaxation of constraints in particular countries. A substantial literature has also developed on the effect of financial reform on a country's real performance for both developed and developing countries.

The area that has been comparatively under-researched is the effect of product market regulation on macroeconomic outcomes, with the exception of the effect of barriers to trade. Yet, by now a number of contributions have appeared that have started redressing this imbalance and have shed light on the overall effects of product market regulation. The main purpose of this paper is to provide a critical overview of the recent empirical contributions that use cross-country data to provide insights on the effect of such product market regulations/reforms on a country’s macroeconomic performance. Although the term "product market regulation” encompasses various dimensions, we will focus on those aspects that affect the degree of competition by contributing to the size of entry barriers or by restricting entrepreneurial choices concerning inputs, supply or pricing.

The evaluation of the cross country evidence is preceded by a discussion, in Section 2, of the main channels through which regulation can affect economic outcomes 
and by a selective review of important micro level studies that are relevant for the issues under discussion. We then discuss in Section 3 the main characteristics of the regulatory data available, the main stylized facts about regulatory reform, and the methodological challenges that researchers face in assessing the causal effect of regulation on performance. Finally, in Section 4, we review the salient empirical contributions in this area. The final outcome measures we focus on are the demand for labour and capital, firms’ innovative activity, productivity and output growth. Intermediate outcome variables are mark-ups and firms' entry, exit, and turnover rates. A summary of the main conclusions is contained in Section 5.

\section{The Effect of product market regulation on macro performance: Channels and related micro evidence}

In this section we start from a discussion of a few theoretical contributions that help us in understanding the complex links that exist between product market regulation and economic performance. We then review selectively micro-econometric studies for individual countries that either address the relationship between competition and performance or discuss the consequences of specific episodes of regulatory reform.

\section{2a. Theoretical considerations}

Product market regulation affects the overall performance of an economy in several ways (see Griffith and Harrison (2004)). It has an impact on the allocation of resources between sectors producing different goods and between firms with different 
productivity within each sector. Moreover, it affects the productivity of existing firms. Finally, it has an impact on the pace of productivity growth by altering the incentives to innovate and by determining the speed with which new products and processes replace old ones.

When regulatory reforms lead to more competitive output markets, the wedge between prices and marginal costs is reduced and the allocation of goods and resources, in the absence of other distortions, will become more efficient in a static sense: more competitive markets will allocate capital and labour more efficiently to the production of those goods that consumers value more. ${ }^{1}$ Even more importantly, a more competitive climate will lead to pressure for the less efficient firms to exit and, through this channel, market shares will shift from lower to higher productivity firms, leading to a more efficient allocation of factors of production.

Blanchard and Giavazzi (2003) discuss the effect of product and labour market regulation on employment and wages in the context of a model of identical imperfectly competitive firms for whom labour is the only factor of production and both the product and labour markets are non competitive. In that model, an increase in product market reform is modelled either as an increase in the degree of substitutability between goods or as a decrease in entry cost.

The effect of product market reform may differ between the short run and the long run. An increase in the degree of substitutability between goods leads in the short run, for a given number of firms, to lower mark-ups, increased employment and higher real wages. However, there is no effect in the long run, because the reduced mark-ups lead to firms'

\footnotetext{
${ }^{1}$ In some situations, for instance in the presence of natural monopolies, simple deregulation, as opposed to regulatory reform, will not necessarily lead to an increase in competition and in the efficiency of resource allocation.
} 
exit. Product market reforms that lead to a decrease in entry costs have, instead, long-run effects as well. The entry of new firms will be associated with a lower mark-up and higher employment and real wages. The fact that only policies that affect the cost of entry have long run effects, and hence are the ones that should receive the greatest attention, is one of the main policy implications of the paper. ${ }^{2}$

Another class of models allows for heterogeneity between firms. Bernard, Eaton, Jenson, and Kortum (2003) and Melitz (2003) focus on external barriers affecting the product market and are based on the assumption of heterogeneity in productivity. These papers allow for entry and exit of firms and show that a lowering of trade barriers generates a reallocation of resources in favour of more productive firms. The exit of low productivity firms and the expansion in the domestic and foreign markets of higher productivity firms gives rise to aggregate productivity growth. ${ }^{3}$

Bergoeing, Loayza and Repetto (2004) also allow for idiosyncratic heterogeneity differences in productivity and focus on how the effect of a negative aggregate productivity shock depends upon government induced rigidities in the reallocation of resources, modelled as a subsidy to existing firms. Simulation exercises show that the existence or the introduction of such subsidies increases the length of the period in which aggregate output is below potential and generates greater cumulated output losses. ${ }^{4}$

\footnotetext{
${ }^{2}$ The effect of labor market reform, captured by a decrease in workers' bargaining power in a Nash cooperative bargain, will lead to a decrease in the real wage in the short run, but to an increase in employment and an unchanged real wage in the long run in the Blanchard and Giavazzi model.

${ }^{3}$ For recent micro evidence on foreign competition and trade reform see Pavnick (2002), Harrison and Revenga (1995), Harrison (1994), Levinsohn (1993). For cross-country evidence on trade liberalization see Rodriguez and Rodrick (2001), Vamvakidis (2002), and Yanikkaya (2003).

${ }^{4}$ Cross sectional cross-country evidence supports the existence of a positive relationship between cumulated GDP losses and the stringency of regulation, controlling for the volatility of shocks affecting the economy, captured by the standard deviation of the terms of trade and of domestic inflation.
} 
Restuccia and Rogerson (2003) and Hsieh and Klenow (2006) develop models in which government generated distortions result in heterogeneity in returns to capital and labour across firms and in misallocation of resources. This misallocation may result in sizeable lower levels of aggregate TFP, as shown by Hsieh and Klenow (2006), using plant level data for India and China.

Product market reforms also have a direct effect on the productive efficiency of existing firms. Greater competition may increase the incentives to reduce Xinefficiencies and organize work more efficiently. The theoretical literature is immense and, while agency models of managerial behaviour can rationalize why greater competition tends to reduce slack, this conclusion is by no mean unambiguous. The channels of transmissions are manifold (Nickell, Nicolitas, and Dryden (1997)). First, in a more competitive environment it may be easier for owners to monitor managers because there are greater opportunities for comparison which can lead to better incentives. Second, it is plausible that an increase in competition will increase the probability of bankruptcy and managers will work harder to avoid this outcome. Third, in more competitive markets characterized by higher demand elasticity, a reduction in costs that allows firms to lower prices will lead to a larger increase in demand and, potentially, profits.

Changes in ownership from public to private may also have important effects on the incentives for managers and workers to reduce slack. Whether or not that happens crucially depends upon the market structure after privatization. One must be careful, in general, not to equate privatization or deregulation automatically with an increase in competitive pressure, particularly in sectors where increasing returns create incentives for the emergence of natural monopolies. 
There are several principal agent models that study the effectiveness of incentives and its dependence on the number of players. One of the papers that address more directly the link between competition and performance is the model by Hart (1983). ${ }^{5}$ In that paper a fraction of firms are run by managers who respond only partially to monetary incentives, in the sense that they care only whether or not their income exceeds (or not) a minimum level. The resulting optimal contract consists of paying managers this minimum provided firms' profits exceed a given floor (that can be interpreted as the bankruptcy level), and zero otherwise. In this situation, any shock that induces profit maximizing firms to reduce costs will be transmitted, via lower equilibrium prices, to non-profit maximizing firms. Their managers will also try to reduce costs in order to avoid bankruptcy and preserve the utility derived from being in control of the firm. This will lead to an increase in the level of productivity in the economy.

However, if we allow managers to respond to monetary incentives, the effect becomes ambiguous. Greater competition increases the threat of bankruptcy, which is a disciplining devise, but at the same time reduces profits in equilibrium, and with it, the possibility to provide monetary incentives to managers (Scharfstein (1988) and Schmidt (1997)).

Product market reforms may affect not only the level of productivity, but also its growth rate through the effect that greater competition has on the incentives to introduce new products or processes that replace the existing ones. The view by Schumpeter (1942) of growth as a process of creative destruction, in which the introduction of new processes and products is associated with the destruction of old ones, underlies many recent papers, such as the endogenous growth models of Aghion and Howitt (1992) and Grossman and

\footnotetext{
${ }^{5}$ See also Holmstrom (1982), Nalebuff and Stiglitz (1983), and Mookherjee (1984).
} 
Helpman (1991) and the contributions by Caballero and Hamour (1994), (1996), (1998). Impediments introduced by product or factor market regulations to reallocation of factors of production away from low return activities to high return ones may have adverse effects on an economy’s aggregate performance. ${ }^{6}$ In endogenous growth models, for instance, product market regulation may be seen as increasing the cost of introducing an innovation.

However, there are contrasting forces at work. In Schumpeter the expectations of monopoly profits provide the crucial incentive for innovative activity. A decrease in monopoly profits following regulatory reform may, therefore, decrease the pace of innovation and hence growth. In addition, the degree of market power also affects the ability to innovate since it allows the accumulation of internal financial resources that can be used to finance innovation. These internally generated funds are crucial in the presence of information asymmetries that may make it difficult or expensive to obtain external funds for innovation activities. Indeed in the early quality ladder endogenous growth models by Aghion and Howitt (1992) and Grossman and Helpman (1991) and in the product variety model by Romer (1990) a reduction in rents generated by regulatory changes would adversely affect the incentive to innovate and, hence, decrease steady state growth. ${ }^{7}$ Both product variety and quality ladder models, moreover, typically exhibits scale effects in the sense that larger economies with more resources that could be

\footnotetext{
${ }^{6}$ See also Parente and Prescott (1994) who argue that the productivity gap across countries is due to excessive regulation that discourages the adoption of new technologies and protects poorly performing firms, thereby slowing the convergence to the world technology frontier.

${ }^{7}$ In the endogenous growth models reviewed here, regulatory reform can be though of as increasing the price elasticity of demand, or decreasing the cost of entry (increasing the probability of entry), or decreasing the cost at which a competitive fringe can produce.
} 
devoted to research grow faster in the steady state. ${ }^{8}$ In this context, product market reform in the form of trade liberalization could have ambiguous effects on growth, since the positive scale effect is counterbalanced by the (negative) effect generated by smaller rents that accrue to innovators.

Note that whereas in the product variety models the decentralized growth rate tends to fall short of the one chosen by the social planner, in quality ladder models of creative destruction this may or may not be the case, basically because the benefits of faster technological progress must be traded off against the losses in rents by the monopoly producers that are displaced. Similar ambiguities in terms of welfare implications appear in models in which relationships are characterized by specificity that generates a hold up problem, such as Caballero and Hammour (1996), (1998). Regulations that make the reallocation of resources costly can lead to technological sclerosis, in which low productivity units are allowed to survive too long. At the same time, they may also cause the reallocation process to be unbalanced, in the sense that the destruction rate is excessive, given the low creation rate, and generates too high unemployment of the factor that appropriates part of the rent.

In the earlier quality ladder growth models referred to above, innovations are made by outsiders and not by the incumbents. In more recent models (Aghion, Harris, Vickers (1997), Aghion, Harris, Howitt, Vickers (2001), Aghion, Bloom, Blundell, Griffith and Howitt (2002), Aghion, Burgess, Redding and Zilibotti (2003), Aghion, Blundell, Griffith, Howitt and Prantl (2003), Aghion and Griffith (2005)) incumbents are allowed to innovate. In these models, the incentive to innovate depends upon the

\footnotetext{
${ }^{8}$ However, minor modifications to the cost of introducing an innovation could eliminate this scale effect (Jones (1999)).
} 
difference between post and pre-innovation rents. Greater competition reduces both, but the latter more than the former, fostering innovation. Basically, competition may stimulate innovation because entry and the threat of entry provide an incentive to innovate in order to escape competition. This effect should be stronger in industries where competition occurs between “neck-and-neck” firms, i.e. firms with similar production costs. In other terms, competition is more likely to stimulate innovation and productivity growth in sectors or countries close to the technological frontier, while the opposite holds for sectors or countries below the frontier. ${ }^{9}$

Finally, there can also be another channel through which increased competition can have a beneficial effect on innovation and growth. When principal agent considerations such as those in Hart (1983) are inserted in an endogenous growth model, greater competitive pressure can provide an incentive for managers to speed up the adoption of new technologies in order to avoid bankruptcy and the loss of benefits from control associated with it (see Aghion, Dewatripont and Rey (1999)).

In summary, there are many ways through which product market regulation may have an impact on overall economic performance. Regulatory reform can affect factor demand and the efficiency with which labour and capital are allocated. It also will have an impact on the extent of managerial slack and on X-inefficiency in existing firms. Moreover, it can exert an influence on the process of firm dynamics and on the

\footnotetext{
${ }^{9}$ See also Vives (2006) for a discussion of the effect of competition on innovation in a variety of models of imperfect competition. The paper makes the point that the theoretical predictions depend upon the measure of competitive pressure used (degree of product substitutability , ease of entry, number of competitors, market size), upon whether one considers markets with restricted (exogenous market structure) or free (endogenous) entry, and upon whether one focuses on product or process innovation. In market with free entry, decreasing entry costs increases the number of firms (variety) but decreases R\&D effort per firm finalized to cost reduction. However, typically total R\&D effort increases. Increasing product substitutability tends to increase R\&D effort per firm but the number of varieties may decrease. In market with restricted entry an increase in the number of firms tends to reduce R\&D effort at the firm level, while increasing product substitutability tends to increase R\&D effort.
} 
introduction of new products and processes, and hence on aggregate productivity growth. However, at the theoretical level there are sufficient ambiguities or caveats concerning the direction of the effect of regulatory reform on innovation that empirical research in this area is absolutely essential to come to a convincing conclusion about the overall impact of product market regulation.

\section{2b. Lessons from micro-econometric evidence}

A seminal micro-econometric contribution that has important implications for the issues we are discussing here is the paper by Nickell (1996), who uses firm level data for the UK to investigate where changes in competition affect productivity levels and growth rates. Competition is measured in several ways, including industry level measures of monopoly rents, concentration, import penetration, and number of competitors. By estimating a dynamic production function with the competition variables as additional regressors, and allowing for endogeneity of input choices, Nickell finds that greater competition has a positive effect both on the level and the growth of productivity. Note that while firm level variables are instrumented in the context of a dynamic panel GMM approach, competition variables are not. However, if an increase in productivity leads a firm to increase its market share, so that the market becomes more concentrated and less competitive, this would impart a downward bias to the estimates of the effect of competition on productivity. In this case, the estimated effect represents a lower bound on the true effect of competition on productivity. 
The results in Nickell are confirmed by the more recent contribution by Disney, Haskel, and Heden (2000), using a larger data set for UK firms. ${ }^{10}$ Klette (1999) extends the approach by Hall (1986), (1988) to estimate market power and concludes, using Norwegian plant level data, that plants characterized by greater market power tend to be less productive. Bottasso and Sembenelli (2001) apply a similar methodology on Italian firm level data and conclude that the EU Single Market Program has led to a decrease in the mark-up and an increase in productivity for those firms that were expected, ex-ante, to be more sensitive to the abolition of external barriers.

There are several other micro-econometric contributions that address the effect of regulatory reform and privatization on productive efficiency or productivity growth. Many of these studies focus on the service sector since regulatory changes have been particularly important in utilities, communication, and in the transport sector. We will not review in detail the evidence here, but the overall conclusion is that in many instances there have been productivity gains due to the increased competition. ${ }^{11}$

An important paper on the effect of regulatory reform on the dynamics of productivity is the one by Olley and Pakes (1996) on the evolution of the US telecommunication industry following deregulation. The industry experienced productivity growth that was not reflective of productivity growth in manufacturing. Olley and Pakes decompose aggregate (weighted) productivity levels between unweighted average productivity and a cross term that captures whether more efficient firms

\footnotetext{
${ }^{10}$ See also Jaganathan and Srinivassan (2000) for a different way of testing the effect of competition on agency problems, based on the relationship between leverage and profits.

${ }^{11}$ For evidence on the effect of the EU Single Market Program on mark-ups and productivity see also, Gagnepain and Marin Uribe (2003), Goldberg and Verboven. (2001) among others. See also Martins, Scarpetta and Pilat (1996) on mark-ups in the OECD. For a review see Ahn (2002), pp. 17-18, Ahn (2001), pp. 24-25, and Faini et al. (2005).
} 
have greater market shares. They use their estimate of production function parameters that control for endogeneity and sample selection to show that improved aggregate productivity performance at the industry level is due to a reallocation of output to more productive plants and not an increase in the un-weighted average productivity.

In addition to the static productivity level decomposition due to Olley and Pakes (1996) between, Baily, Hulten and Capbell (1992) have proposed to decompose aggregate productivity growth in different components. Their contribution has been refined by Griliches and Regev (1995) and by Foster, Haltiwanger and Krizan (2001). The basic idea is to beak down aggregate productivity growth in a "within" component (coming from productivity improvement in continuing firms), a "between” component (due to the reallocation of resources between continuing firms), and of the component due to entry and exit. ${ }^{12}$ The refinements attempt to deal with the overestimate of the contribution of entering and exiting firms inherent in Baily et al, by introducing reference productivity values in calculating the contribution of such firms. Results on the relative importance of each component of total productivity growth decompositions differ according to which decomposition is used, to whether one focuses on multi-factor or labour productivity, whether one uses employment or product weights, whether they are beginning of period or an average between the beginning and the end of period, and according to the length of the horizon chosen for the calculation. Many estimates of the within component of labour productivity imply that it tends to be the most important component, although its weight varies across studies. Bartelsman, Haltiwanger and Scarpetta (2004), find that this is the case both in developed and non-transition emerging

\footnotetext{
${ }^{12}$ See Haltiwanger (2000) and Ahn (2001) for a review. In some decompositions, in addition to the "within", "between" and entry/exit component s there is also a "cross" component.
} 
countries. Foster, Haltiwanger, and Krizan (2001) show that the contribution of entry and exit (net entry) to aggregate productivity becomes important (and positive) only at a 5/10 year horizon, reflecting the increasing share of entering/exiting firms and learning/selection effects. Bartelsman et al (2004) also show that entry is more important (and positive) in most transition countries. The entry contribution tends, instead, to be negative in most OECD countries and in the non transition emerging economies, while the exit effect is always positive. Evidence on the importance of reallocation of market shares from low to high productivity continuing firms is also mixed. For instance Grilliches and Regev (1995), and Scarpetta, Hemmings, Tressel and Woo (2002) find that it is small, whereas Baily, Hulten and Campbell (1992), and Foster et al. (2001) find it is important. Recently Melitz and Polanec (2008) have argued that even the Griliches and Regev (1995) and Foster et al. (2001) decompositions underestimate the contribution of surviving firms and overestimate the contribution of entering firms and propose a new decomposition based on Olley and Pakes (1996) that indeed enhances the empirical importance of productivity developments for the set of continuing firms, particularly of the between component.

There is little micro based evidence on how product market regulation affects different components of productivity growth or of productivity levels, especially for developing counties. The available cross country evidence will be discusses later. ${ }^{13}$ Some A few contributions exist for individual countries. Useful information for India is contained in Srivastava (1996) who analyzes the effect of the first phase of industrial deregulation in India in 1985, involving a significant degree of de-licensing of entry and

\footnotetext{
${ }^{13}$ See Section 4d, pp. 44-45.
} 
expansion and liberalization of intermediate and capital imports. ${ }^{14}$ Using production function estimates based on firm level panel data, he shows that the rate of TFP growth for existing firms increased after deregulation. The increase was particularly evident in those sectors with an above average use of imported materials. More recently, Arnold, Javorcik, Lipscomb, and Mattoo (2008), using firm level panel data, provide evidence that reforms in the service sectors in India (telecommunication, transport, and banking) have had significant positive effects on the productivity of both foreign and locally owned manufacturing firms. The effect on foreign firms tend to be larger.

Finally, Aghion, Burgess, Redding, and Zilibotti (2005), using a panel of industry/state level data, provide evidence that de-regulating entry in India in 1985 and 1991 has not had an identifiable effect on entry, but it has increased the dispersion of output levels across establishments. Moreover, they show that output increases more after product market deregulation if labour market regulation is less restrictive. The interaction between product and labour market reform is an important issue that deserves further investigation.

Let us turn now to the relationship between innovation and the degree of competition, remembering that the latter can be effected by product market regulation. The empirical results are mixed and suggest that there is not a simple linear relationship between competition and innovation. ${ }^{15}$ Most studies, particularly the earlier ones, were conducted at the industry level and they tended to rely on concentration as a measure of competition, which is problematic because the measure of concentration does not capture

\footnotetext{
${ }^{14}$. See Heckman and Pages (2003) on the effect of labour market regulation in Latin America. See also Eslava, Haltiwanger, Kugler, and Kugler (2005) for evidence on the effect of factor market reform on employment adjustment, capital adjustment and productivity using a panel of plants in Columbia.

${ }^{15}$ See Ahn (2002) for a review. See also Geroski (1995)
} 
the competitive pressure coming from potential entrants. The overall results are not supportive of the proposition that concentration exerts an unambiguous positive effect on innovation activities. ${ }^{16}$

More recently, Blundell, Griffith and Van Reenen (1999) found, using UK firm level data, that firms with greater market share were more innovative, but that more competitive industries produced more innovation. Recent firm level evidence suggests that the relationship between mark-ups and innovation is non linear and has an inverted $\mathrm{U}$ shape, as suggested by the most recent growth models. Aghion, Bloom, Blundell, Griffith and Howitt (2005) use data on listed UK firms for which weighted patents measures of innovation are available. The Lerner index is used as a measure of competition and the problem of its endogeneity is addressed by using as instruments reforms linked to the EU single market, reforms imposed on individual sectors as a result of action by the UK competition authorities, and measures of privatization. The results are supportive of an inverted $\mathrm{U}$ shape relationship with innovations being adversely affected by a very competitive or very monopolistic environment. Note that a linear specification would yield a positive relationship between innovation and measures of rents, as suggested by Schumpeter. The results concerning the $\mathrm{U}$ shape are stronger in neck-and-neck industries, as suggested by the theory.

Aghion, Blundell, Griffith, Howitt, and Prantl (2005) analyze the effect of foreign firm entry on TFP growth and patent counts. Obviously, entry is endogenous and the latter is instrumented with policy and foreign technology variables that are less likely to have a direct effect on the growth of TFP or on patents. Using individual UK firm data, entry is found to have a positive, significant and sizeable effect on TFP. The effect is

\footnotetext{
${ }^{16}$ See Cohen and Levin (1989).
} 
greater when IV procedures are used and it is greater for an industry closer to the technological frontier.

\section{Data and methodological issues}

In this section, we will review the main data on regulation that are available across countries and that have been used in empirical work. We will also discuss the main stylized fact that can be identified from the data. The available measures of regulation condition the type of econometric evidence that can be produced, and often it represents an important constraint for the researcher. Although there are serious issues in measuring economic outcomes, such as total factor productivity growth or firm’s innovative activities, they are arguably not as severe as those affecting the measurement of tightness of regulation. ${ }^{17}$

We also discuss other important methodological issues involved in estimating the effect of regulation on economic activity. The main issue here is to go beyond any observed statistical association between regulation and performance and draw inferences on the causal effect of regulation on economic outcomes.

\section{3a. Data and stylized facts}

Product market regulation varies by countries and time and often is industry specific. Moreover, the term “product market regulation” encompasses various dimensions that exert different effects on agents’ behavior. A very important aspect one would like to capture is how regulation contributes, directly or indirectly, to the size of

\footnotetext{
${ }^{17}$ See for instance Basu and Kimball (1997) on the problems in measuring productivity growth.
} 
entry barriers. Regulation also affects conduct by restricting entrepreneurial choices concerning inputs, supply or pricing.

Many of these regulations are justified as attempts to address market failures due to the existence of natural monopolies, informational frictions, or externalities. Whether this indeed is the case or whether regulation results from the interaction between the desire of politicians to be re-elected and the pressure of interest groups in pursuit of their private gains and results in even greater government failures has been hotly debated. However, this is not the issue we want to address in this paper. For our purpose, we simply note that product market regulation tends to restrict competition and this has potentially important economic consequences. Yet, there are conceptual and practical problems in measuring those dimensions of regulation that are relevant in shaping the competitive environment. Moreover, often the data are not available at the industrycountry level, but only at the country level, and/or they are available at only one point in time or at widely spaced intervals.

One of the main data sets used in empirical work on the effect of regulation is collected by the Fraser Institute and it contains information (in the interval 1 to 10 , decreasing with stringency of regulation) on price controls, time spent with bureaucracy, ease of starting a new business, government transfers and subsidies (as a \% of GDP), government enterprises and government investment (as a \% of GDP), non-tariff import barriers, and average tariffs. The indicators reflect a mixture of factual information and perception and are available up to 2000 at five year intervals. After that, they are available at a yearly frequency. No sectoral disaggregation of the indices is available. 
Another useful data set is the OECD database on regulatory reforms containing detailed economy wide information for 1998 and 2003 on regulations and administrative burdens on existing and new business. ${ }^{18}$ For a subset of industries (electricity, gas, air passenger transport, rail transport, postal services, and telecommunications) indices of the importance of barriers to entry, vertical integration, market structure, price controls, and of the importance of public ownership are available on an annual basis from 1975 to 2003 (the indices range from 0 to 6 and are increasing with the stringency of regulation). For these sectors, the data availability comes as close as possible to what a researcher would want. Sectoral indicators are available for 1998 and 2003 for retail trade and professional services, covering both entry regulations and conduct regulation. ${ }^{19}$ For manufacturing, no time varying data measuring regulation are available at an annual frequency, except data on tariff and non tariff barriers, public ownership, and restrictions on foreign direct investment. However, the OECD data set includes measures at the two digit level of the 'knock-on' effect of non-manufacturing regulation on all sectors. It is calculated using the indicators for non-manufacturing sectors and the importance of these sectors as suppliers of intermediate inputs to other sectors (including manufacturing), measured from input-output tables.

For European countries, one can also obtain further information on the evolution of state intervention in the economy, using the Eurostat data on sectoral and ad hoc state aid (\% of GDP), public procurement (as \% of GDP), and openly advertised public procurement (\% of procurement) for the nineties. Another useful source of data is the

\footnotetext{
${ }^{18}$ See and Conway and Nicoletti (2006). See also Conway,. Janod and G. Nicoletti (2005) and Nicoletti, Scarpetta e Boylaud (1999) for economy wide indicators of product market regulation.

${ }^{19}$ See Nicoletti and Pryor (2006) for evidence that the OECD economy wide indicators and the Fraser Institute indicators are highly correlated, in spite of the different methodology used in their construction.
} 
European Centre for Public Enterprises with Public Participation (CEEP) that provides information on the share of public enterprises in the business sector at $4 / 5$ year intervals.

As we have seen, there is greater data availability on various aspects of product market regulation for developed countries. An important source of information that covers developing countries and transition economies as well is the World Bank "Doing Business” database. It contains information on the ease of starting a new business, including the number of procedures, the time involved, and their cost. The data set is based in part on, and expands, the design in Djankov, La Porta, Lopes de Silanes, and Shleifer (2000). It also provides useful information on other dimensions of the business environment, such as dealing with licenses, hiring and firing workers, closing a business, paying taxes, etc. Unfortunately these indices are available only for the period 19962002 at a biannual frequency, and lack industry details.

The World Bank also produces the Investment Climate Assessment survey containing information for several developing and transition countries on individual firms' perception about the investment climate. ${ }^{20}$ It includes information about the time spent dealing with government regulation, the time it takes to get a telephone installed, bribes as a percentage of annual sales, and the perception about property rights and the legal system and about labour market regulation as an obstacle to economic activity. ${ }^{21}$ The individual answers can be aggregated at the industry level to obtain a sector specific measure of regulation. The information for the time being is mostly cross sectional, although this may change with the completion of further waves of the surveys.

\footnotetext{
${ }^{20}$ See www. enterprisesurveys.org.

${ }^{21}$ It also contains retrospective information for three years on basic balance sheet items.
} 
What are the main stylized facts about product market regulation that can be identified from the data sets we have described? First, regulatory burdens vary widely across the world. In particular, regulation tends to be more stringent in poor countries compared with richer countries. There is also evidence that it is greater in countries with a French legal origin or with a socialist legal origin. Second, the dispersion of regulatory regimes is greater in developing countries relative to developed countries. Third, there has been a generalized tendency towards the relaxation of regulation concerning entry. This has been accompanied by a decrease over time in tariff and non-tariff barriers to trade in manufacturing. Fourth, there has been a substantial movement towards less restrictive regulation in many developing countries, including India and China. Fifth, OECD countries have experienced substantial deregulation in services, in sectors such as telecommunication, utilities, and transport. The timing and extent of regulatory reform has varied considerably, with the US moving first in the early 80’s. The UK, Canada, New Zealand, the Nordic European countries started to reform a little later, in the mid 80's. In Australia and most other European countries market reform occurred from the mid-90’s on and has been less decisive in countries such as France, Italy and Greece. Finally, often regulatory reform has been accompanied by privatization, so that there has been a tendency for the share of output produced by public enterprises to decrease. ${ }^{22}$

\section{$\underline{\text { 3b. Methodological issues }}$}

The main methodological issue facing researchers working in this area is to go beyond any observed statistical association between regulation and performance and draw inferences on the effect of regulation on economic outcomes. In doing so, it is

\footnotetext{
${ }^{22}$ See also Crafts (2006) for an overview of regulation and its effect on productivity.
} 
important to control for observed and unobserved factors that have an effect on performance independently from the regulatory environment. Most papers make a serious effort in controlling for observed factors. The main issue involves unobserved heterogeneity.

If outcomes are measured at the industry level and the type, level and change in regulation is also industry specific, the availability of time varying industry specific indicators allows one to control for time invariant country and industry effects. It can also allow one to control for factors that vary over time and are common across sectors, like technological innovations or knowledge that are widely accessible by all countries or common macro shocks. If the time varying information on regulation is only country specific, but there continues to be time varying industry specificity in regulation, the measurement error problem may bias the coefficient on regulation towards zero and make it more difficult to detect the true effect of regulatory changes. At a minimum, it would be desirable to distinguish between regulation in manufacturing and in service industries. Yet, in the case that common regulatory changes are dominant, time varying indices at the country level are useful in that one can control, at least, for country and sector specific time invariant characteristics.

If the time dimension is not available, industry variation in the product market regulation indicators is still helpful, because, at least one can control for additive unobserved country and industry specific effects ( but not for country specific industry effects). All the identification in this case comes from cross-sectional country/sector variation in the data. 
However, often one has available information that varies only by country, with no industry specificity. This makes it very hard to distinguish the effect of product market regulation from other country specific unobservable effects. In assessing a country’s aggregate performance, some mileage here can be gained by using interaction effects with other variables that vary by country and time. For instance, one may believe that the effect of regulation may be different depending upon circumstances such as distance of a country from the technological frontier, etc. The lack of identification of the main effect of regulation from other country specific effects remains.

A distinct, and less relevant problem in this area of research, occurs when one only has country specific information on regulation even if the latter is truly the only one that matters because there is no industry specificity, yet one uses outcomes at the industry level as a dependent variable. Moulton (1990) points out that standard errors for the coefficient of the variable (regulation) that varies only by country can be seriously underestimated when the error terms are contemporaneously correlated across industries within countries. The severity of the problem and the appropriate solutions is related, among other things, to the number of groups (countries in our context). If the number of groups is large, things are simpler, although one has to allow for the potential contemporaneous correlation in the error term across sectors within a country in calculating the standard errors. Things are more complicated if the number of groups is small (see Wooldridge (2003) for an overview).

Another, more important, issue is the potential endogeneity of regulation itself, even if one controls for country and industry time invariant effects. Regulation is the result of a political decision process that may indeed be influenced by the economic 
performance of a country or of an industry. It is difficult to say a priori in which direction the bias would work. For instance, negative macro shocks, particularly if prolonged, can enhance the probability of reforms because the unsatisfactory nature of the status quo weakens opposition to reform. However, it may be easier to introduce reform in good times because their negative impact on particular groups may be smaller and/or there are more resources to compensate the losers. In the first case, OLS or within estimators may lead to an underestimate of the true effect of reform, in the latter case, such effects will be overestimated. Recent empirical evidence for OECD countries suggests that poor growth experience in a given year (or in the recent past) leads to less regulated output markets. ${ }^{23}$ Similar results hold for trade reform, but, interestingly, not for financial or labour market reform. ${ }^{24}$ No systematic evidence is available for developing countries, although it is not unreasonable to conjecture that similar patterns may be observed for product market and trade regulation. The result of all this is that there is the risk of underestimating the effect of product market reforms, since the outcome variables one is interested in are generally procyclical, including standard measure of productivity.

\section{Product Market Regulation and Economic Performance: Review of Cross- country Evidence}

In this section, we will review a set of recent contributions that have a direct bearing on the effect of product market regulation on various aspects of macroeconomic performance. The review will be selective and focus on papers that provide cross-country

\footnotetext{
${ }^{23}$ See IMF economic Outlook, 2004, ch. III “Fostering Structural Reforms in Industrial Countries”.

${ }^{24}$ A contemporaneous bad year increases labour market regulation and past weak growth is associated with tighter financial regulation.
} 
evidence. In many cases, researchers have adopted a reduced form approach and have entered measures of regulation as an explanatory variable in equations for factor demand, productivity or innovation. In other cases, the effect of regulation is mediated through its effect on an intermediate variable, such as the mark-up or firms' entry, exit, and turnover rates. We will start from reviewing the evidence on the effect of regulation on these "intermediate" variables, and we will then discuss the effect of regulation on the ultimate outcome variables, such as investment, employment, innovation, productivity, and output growth.

4a. Transmission mechanism: Effect on mark-up and firms' entry/exit/turnover

Griffith and Harrison (2004) is a good example of the two step strategy in estimating the effect of product market regulation. In the first step, they first estimate the effect of product market reforms on the level of rents, measured by the ratio between value added and the sum of labour and capital costs. The effect of variations in the markup on factor accumulation $\mathrm{R} \& \mathrm{D}$ and productivity is estimated next, using product market reforms as an instrument for the clearly endogenous mark-up. This approach is legitimate under the assumption that product market reforms affects the economy only through mark-up variations and not directly. Since this may or may not be the case, it is important to assess through a test of over-identifying restriction whether this assumption is or is not rejected.

Griffith and Harrison only use regulations that vary with time across countries in order to be able to control for cross- sectional unobservable differences that are relatively constant over time. The indicators of product market regulation are the Fraser Institute 
index of ease of starting a new business, of price controls, of time spent with government bureaucracy, average tariff rates, of regulatory trade barriers, the European Center of Enterprises with Public Participation, and the Eurostat Structural indicators on state aid, on public procurement, and on the percentage of it that is publicly advertised. The indicators are interpolated or extrapolated if not available for each year and are entered separately in the equations. Both in the mark-up and factor demand equation they control for country specific cyclical factors. Their results suggest that many of the indicators measuring tightness of regulation have a significant positive effect on mark-ups, as one would expect. The effect of variations of mark-ups on various economic outcomes will be discussed below.

Several authors extend and modify the two step approach found in Griffith and Harrison (2004), by choosing a different intermediate variable to focus on. Cincera and Galgau (2005) estimate first the effect of regulation on entry and exit of new firms and then the effect of entry and exit on factor demand and productivity. Loayza, Oviedo and Serven (2005) use firm turnover rates (the number of exiting and entering firms divided by the total number of firms) as the intermediate variable and investigate its effect on productivity growth and its components. Scarpetta, Hemmings, Tressel and Woo (2002), Brandt (2004) and Klapper, Laeven, and Rajan (2004) present results on the effect of regulation on entry, but do not investigate the relationship between entry and other economic outcomes.

Data sources for entry and exit rate vary across studies. The entry and exit rate variables in Cincera and Galgau (2005) are taken from the DUN \& BRADSTREET data base on the number of entries and exits for 352 digits sectors for 9 OECD countries. The 
data on firm dynamics in Loayza et al. cover six Latin American countries and nine industrial economies and are taken from the harmonized data set on firm dynamics constructed by Bartelsman, Haltiwanger and Scarpetta (2004). The entry and exit rates in Scarpetta et al. and Brandt are taken, instead, from the OECD firm level data base constructed from business registers or social security databases. Klapper et al. (2004) use the cross-country firm level Amadeus data set to construct entry rates for Western and Eastern European countries. In most cases the time dimension of the data on entry and exit tends to be rather short. ${ }^{25}$

The results obtained by Cincera and Galgau, using the first principal component of the Fraser Institute and the within estimator, suggest that deregulation tends to be significantly associated with more entry and exit. ${ }^{26}$ When the coefficient on regulation is allowed to differ across sectors the results are not tidy, with the sign and significance varying across sectors. Similarly, allowing for country variations, suggest heterogeneity of responses that are not easy to rationalize.

Scarpetta et al. (2002) use as explanatory variable, the time invariant OECD indicators, either country or country/sector specific. When only country level indicators are used, one obviously cannot control for country specific effects. When industry/country specific indices are used, the authors control for country and industry additive effects. The more convincing results are those in which they control for country and sector effects in the specification also including employment protection indices.

\footnotetext{
${ }^{25}$ For instance, the data for firm demographic refer to the period 1997-2003 for most countries in Cincera (2004), and to 1998 and 1999 in Klapper et al. (2004). In Loayza et al (2005) the period is somewhat longer (1990-2001) for some countries, but not for others.

${ }^{26}$ In the estimating equation, the author controls for lagged entry, capital and R\&D intensity as a measure of barrier to entry, and other market structure variables, as a measure of opportunities, in addition to year, country and sector effects. Note that the use of the within estimator even in a dynamic equation with short $\mathrm{T}$ is not appropriate.
} 
Product and labour market regulations indices are interacted with firm size dummies. There is evidence that for firms from 20 to 99 workers product market regulation has a negative and significant effect on entry. For the 100 to 499 class the effect is positive and significant, which is somewhat puzzling.

The results by Brandt (2004) are obtained using country specific time invariant measures of barriers to entrepreneurship as the explanatory variable in an equation in which the dependent variable is the averaged residual (across sectors and time) of a regression of entry rate on industry, time dummies, and country specific ICT industries dummies. The focus on barrier to entry is motivated by the fact that some of its subcomponents are the only ones to have some explanatory power. This is not true for indicators summarizing state control and barriers to trade and investment. The barriers to entry coefficient is not significant, however there is some evidence that its subcomponent representing regulatory and administrative opacity has some explanatory power for entry rates.

Klapper et al. (2004) focuses on the interaction effect between regulation and the “normal” rate of entry in an industry, proxied by the corresponding entry or turnover rate for the US. The drawback is that one cannot make a statement about the overall effect of regulation on entry, but only on relative magnitudes. The advantage is that this approach should be less affected by reversed causality problems, whereas in countries with generally low entry there may be less pressure to eliminate restrictive regulations. The 
results suggest that regulation reduces entry relative to the "normal” industry specific rate one observes in a country (the US) with low barriers to entry. ${ }^{27}$

Loayza et al. (2005) emphasizes that the extent of firm dynamics depends also upon the volatility of the shocks affecting each country. In particular, they include in the equations for entry, exit and turnover the triple interaction between regulation, normal turnover (in the US), and the standard deviation of terms of trade growth. In this case, the question is whether economies react differently to shocks depending upon the nature of each sector and the nature of country level regulation. ${ }^{28}$ The evidence is supportive of the idea that product market regulation slows down the reallocation of resources following a shock.

Summarizing, there is substantial evidence that product market regulation leads to higher mark-ups of prices over costs. Considering all the empirical contributions on the relationship between regulation and firm dynamics together leads to the conclusion that regulatory barriers in the product market have a negative effect on firm’s entry or turnover and are likely to slow the process of reallocation of resources.

\section{$\underline{\text { b. Effect of product market regulation (PMR) on fixed capital and labour demand }}$}

In this subsection we will review the empirical results on the effect of product market regulation first on investment and then on employment (unemployment). Alesina, Ardagna, Nicoletti, Schiantarelli (2005) uses country/sector time varying information on

\footnotetext{
${ }^{27}$ Klapper et al. use the time invariant measures on barrier to entry in Diankov et al. (2002). The equations contain also country, industry, size and year effects. In one specification regulation is instrumented by country of origin, with no fundamental change to the results.

${ }^{28}$ Loayza et al. construct a time invariant summary measure of regulation based on information from the World Bank, the Heritage Foundation, and the Fraser Institute. The statistics for firm demographic cover the period 1990-2001, while productivity refers to the 1988-200 period. The equations contain also country, industry, size and year effects. The paper also studies the effect of labor market regulation and fiscal burden.
} 
regulation to assess its effect on capital accumulation by introducing regulation indicators directly in the investment equation. Understanding the behaviour of investment is very important for many reasons, including the fact that often process innovations are embodied in new capital goods. The theoretical model that underlies their contribution is an extension of Blanchard and Giavazzi (2003) that assumes perfectly competitive labour markets but introduces capital as a factor of production that is costly to adjust. Product market regulation affects the size of the mark-up by altering, for instance, entry barriers. Moreover regulation can influence the cost that even existing firms face when expanding their capital stock. ${ }^{29}$ Regulatory reform that generates a decrease of the mark-up or in the cost of adjusting capital is shown to lead to an increased demand for capital. There may be however contrary forces at work. For instance, regulation may impose a ceiling in certain sectors on the rate of return. If such a ceiling is binding, a removal of the constraint may reduce the demand for capital. Moreover, deregulation has sometimes been accompanied by privatization. The reduced importance of a dominant publicly owned player facing a soft budget constraint is equivalent to a reduction in entry barriers. However, public enterprises may have been heavy investors, either because of a political mandate imposed of them or because of their incentives to over expand either because they are empire builders or because they want to maximize political support.

In their empirical work Alesina et al. focus on investment in non manufacturing industries (utilities, communications and transport) in OECD countries that have experienced profound changes, particularly in the 1990's, in their regulatory framework. They use time varying sector-country specific measures of regulation collected by the OECD for the period 1975-1998. In their investment rate equation, they allow for a

\footnotetext{
${ }^{29}$ The model allows for quadratic adjustment costs in capital.
} 
sector-country specific fixed effect and, in some specification, for a sector specific time trend. This is very important because one needs to control for sector specific technological shocks that were occurring at the time of regulatory reform and to which reform itself may be responding.

The overall results suggest that a reduction in regulation, particularly if it affects barriers to entry, has a significant and sizeable positive effect on the investment rate. The results are robust with respect to the inclusion of several country or sector specific controls and to estimating the model in difference by GMM, where the regulatory index is also instrumented with lagged values of itself, with population, GDP per capita, cumulative years of left wing government, and union density (see Djankov et al (2002) on the determinants of regulation). When the specification also includes measures of public ownership, the effect of a reduction in entry barriers remains significant. The coefficient of indices of public ownership is also significant, and its sign suggest that privatization has a positive effect on investment. Finally, there is evidence of non linearities in the sense that more decisive and deeper deregulations have a greater marginal impact on investment. Moreover, the marginal effects of deregulation are greater when one starts from a more deregulated environment. Note that the positive effect of deregulation on investment not only reflects a static reallocation of resources, but may also have growth effects, if new technologies are embodied in new capital goods.

There are several contributions that analyze the effect of product market regulation on employment or unemployment. Typically researchers control for cyclical factors and for labour market policies and institutions and, in some cases, the interaction between product and labour market regulation is considered. It is not the place here to 
provide a review of the copious literature on the effect of labour market regulation on employment (unemployment). Substantial debates exist on how to measure labour market regulation and on its effects. ${ }^{30}$ My reading of the literature suggests that the more up to date evidence supports a negative effect on employment of union density and of the generosity of the unemployment benefit system. The effect of employment protection legislation is more ambiguous, as well as the effect of the degree of coordination/centralization of the bargaining system. Most studies find a negative effect of product market regulation on employment, but there is disagreement on whether product market deregulation is more effective at the margin in highly regulated labour markets. ${ }^{31}$ The most recent evidence is contained in Fiori, Nicoletti, Scarpetta and Schiantarelli (2007) and is based on estimating a dynamic specification of the employment rate equation for the business sector in OECD countries that includes country specific constants and trends and controlling for the endogeneity of policies. The evidence suggests that gains from reducing barriers to entry in product markets are larger when labour market policies are tight. In addition, using summary measures of labour market policies, they find evidence that domestic product market deregulation generates a decline in the bargaining power of workers by promoting deregulation of labour markets or by affecting union density and coverage. The authors show that these results are largely consistent with an enhanced version of the Blanchard and Giavazzi (2003)

\footnotetext{
${ }^{30}$ See Nickell, Nunziata and Oechel (2005) and Bassanini and Duval (2006) as an example of recent econometric work on the effects on unemployment/employment of labour market polices and institutions. Se also Blanchard and Wolfers (2000) for an emphasis on how labour market regulation influences the effect of macro shocks. For a critical discussion of standard ways to measure labour market regulation and for evidence for developing countries, see Heckman and Pages (2003). For a (particularly) critical assessment of the studies emphasizing the negative effect of protective labour market institutions see Howell, Baker, Glyn and Schmidt (2007).

${ }^{31}$ Griffith, Harrison and McCartney (2007) and Amable, Demmou and Gatti (2007) find that high labour market regulation enhances the effect of product market deregulation, while Bassanini and Duval (2006) and Berger and Danninger (2006) find the opposite.
} 
model of bargaining, once one allows for a fuller specification of the fallback position of the union.

Evidence on factor demand, using the two step approach, is provided by Griffith and Harrison (2004), via the mark-up, and by Cincera and Galgau (2005), via entry. After showing that a decrease in regulation leads to a significant decrease in the mark-up, the results in Griffith and Harrison suggest that the mark-up is negatively and significantly related to employment and investment (see below in $4 \mathrm{~d}$ for the effect on $\mathrm{R} \& \mathrm{D}$ and productivity). However, in both cases the test of over-identifying restriction strongly rejects the model, meaning that some of the regulation indicators have a direct effect on employment and investment, besides having an effect through the mark-up. Taking account also of their direct effect leads to the conclusion that the more important effect on labour and investment comes from the average tariff rate (negative), from price controls (negative), and from the CEEP measure of the importance of public enterprises (negative). Re-estimation of the employment and investment model reveals that services are responsible for the conclusion that an increase in competition stimulates factor demand, while this is not (or less) true for manufacturing.

Cincera and Galgau (2005) use firm entry and exit rates as the intermediate variable through which regulation affects various aspects of performance. Obviously, the entry and exit rates are endogenous and need instrumenting. ${ }^{32}$ The instrument chosen by Cincera and Galgau are current and lagged values of the first principal component of the Fraser indices and an index of restrictions on FDI investment, which vary only by country and account only for a portion of the industry level variation of entry. For this

\footnotetext{
${ }^{32}$ Brandt (2004) also present correlation between entry and measures of economic performance, but given the endogeneity problem, it is difficult what to make of them.
} 
reason, current and lagged values of the number of active, entering, and exiting firms are used as additional instruments, which is a more questionable choice. Lack of rejection by the Sargan test of the over-identifying restrictions is not reassuring. If anything, it reminds us of the low power of the test in many circumstances, particularly when many of the instruments have a low explanatory power in the first stage regression. Be that as it may, the results suggest that entry is not a significant determinant of the growth in investment, while exit is associated with a significant decrease in the pace of capital accumulation. For employment growth, the effect is not significant or of different sign at different lag lengths of entry, but with a close to zero net effect.

Summarizing, the direct evidence in Alesina et al. (2004) and the indirect one, via effects on the mark-up in Griffith et al (2004) suggest a positive effect of deregulation on investment and employment in the service sector. For manufacturing, there is no evidence of a positive (or for that matter, negative) effect. The evidence in Fiori et al. (2007) for the business sector also suggests that employment gains from reducing barriers to entry in product markets are larger when labour market policies are tight. Moreover, there is some evidence that product market deregulation promotes deregulation of labour markets. The results in Cincera and Galgau (2005) suggest that entry is not a key channel of transmission of regulatory changes to the reallocation of labour and capital.

\section{4c. Effect of PMR on innovation}

Bassanini and Ernst (2002) present direct evidence for eighteen manufacturing industries in eighteen OECD countries on the effect of product and labour market regulation on $R \& D$ intensity (relative to output). $R \& D$ is used as an input based measure 
of innovative activities by a firm. The advantage of this measure is the fact that it is more easily available than other measures such as patent counts. The drawback is that R\&D is not the only input in the innovation process and, even if it were, $R \& D$ intensity may not capture changes in its effectiveness. Finally, not all innovative efforts are measured by formal R\&D spending. The regulation variables are the OECD country level time invariant measures of domestic economic regulation (state control, legal barriers to entry, price controls) and administrative regulation (administrative barriers for new firms, permit and licensing systems), in addition to time varying indicators of tariffs and nontariff barriers. A measure of protection of intellectual property rights is also included. Controls include industry and country dummies in addition to employment share of large firms and import penetration. As a result, the main effect of the time invariant indices of regulation cannot be estimated, only its differential impact across some cut in the data (high tech versus low tech industries in this case).

The results suggest that non-tariff barriers have a negative effect on $R \& D$ intensity. No effect of tariff barriers is detected, although one wonders whether the presence of the import penetration variable as a regressor or the lack of variation of this indicator across EU countries may be responsible for this result. There is no evidence of a differential effect of domestic or administrative barriers comparing low tech to high tech firms. In contrast, there is a positive differential effect for employment protection in high tech industries relative to low tech in centralized systems of industrial relations. Note however that the high tech-centralized industrial relation system interaction has a negative coefficient. 
Griffith and Harrison (2004) analyze also the effect of (time varying) product market regulation on R\&D through changes in the mark-up. Even allowing for a quadratic term, for virtually all countries the mark-up has a positive and significant effect on R\&D. Also, in this case, the test of over-identifying restrictions suggests that some of the indicators should be included directly in the equation. The results suggest that a lower tariff rate, fewer barriers to starting a business and lower regulatory trade barriers are associated with lower R\&D in the business sector. The results obtained for the manufacturing sector are similar. However, they are very sensitive to the inclusion of Finland in the sample. When Finland is excluded, one obtains a strong inverted $U$ shaped relationship between R\&D spending and the mark-up, with a few countries such as France, Italy and the Netherlands mostly on the downward sloping section, which implies that for these countries an increase in competition would spur innovation, while the opposite is true for the rest of the countries. The sensitivity of the results to country sample selection deserves to be investigated further. ${ }^{33}$

Cincera and Galgau (2005) find a negative effect of entry on R\&D intensity that is significant at the $10 \%$ level. Recall that entry is negatively related to the tightness of regulation. The effect on the $R \& D$ spending growth rate is significantly positive contemporaneously and negative after one year. The net effect is close to zero.

Summing up, the cross-country studies are not supportive of a strong positive effect of lower regulation on direct input measures of firms' innovative activities. Actually, the evidence suggests that lower mark-ups associated with product market reform lead to lower R\&D for most countries. However, this evidence is sensitive in

\footnotetext{
${ }^{33}$ Very recent empirical work conducted at the Institute for Fiscal Studies and still in a draft stage confirms that the inclusion or exclusion of Scandinavian countries affects deeply the shape of the relationship between the mark-up and innovation. I thank R. Griffith for useful comments and information on this point.
} 
manufacturing to the particular sample of countries selected for estimation. Note that, on the whole, this evidence is less supportive of a positive role for competition in fostering innovation than the micro evidence discussed in section $2 \mathrm{~b}$.

\section{4d. Effect of PMR on productivity and output growth}

There are several papers that address the relationship between product market regulation and productivity or output growth. In an early contribution, Koediik and Kremers (1996) find a negative cross sectional relationship between per capita GDP growth or TFP growth and product market regulation in eleven European countries. More recently, using the economic freedom index published by the Fraser Institute and averaging data over five year periods, Card and Freeman (2004) fail to find a significant effect of regulation on the level of output per capita (or per worker) or on its growth rate, once they control for year and country effects ${ }^{34}$.

Nicoletti and Scarpetta (2003) provide the more detailed empirical contribution on this issue. They focus on the effect of regulation on total factor productivity growth, using cross-country data for several industrial sectors and including the regulatory variable directly in the productivity equation. Their approach is inspired by the contribution by Griffith, Redding, and Van Reenen (2004), (2003) who use an endogenous growth model to rationalize both a direct effect of $R \& D$ on growth through its effect on innovation creation, and an indirect one through the absorption of new technology. The importance of the indirect one depends positively upon the distance from

\footnotetext{
${ }^{34}$ The only significant effect is on employment growth.
} 
the world frontier of each industry. The authors substitute R\&D with their measure of product market regulation and also allow for a direct and indirect effect. ${ }^{35}$

The productivity measure is calculated for seventeen manufacturing and six service industries for eighteen OECD countries. Three sets of results are presented. In the first one the authors use the wide coverage, but time invariant country level measures of liberalization collected by the OECD in 1998 (which is towards the end of their sample period). The regulation variables are not significant on their own in regressions that do not (cannot) include a country effect. They are significant when interacted with the technology gap in an equation that lacks country effect. The latter could have been used instead of the insignificant time invariant indicators, in order to make a more robust statement about the significance of the differential effect of regulation, depending upon the technology gap. The time invariant character of the indicators precludes an assessment of the significance of the total effect that is robust to unobserved country heterogeneity.

The time varying measures of privatisation are introduced on their own and they tend to have a positive and significant effect on productivity growth. When a time varying economy wide measure of liberalization that summarizes information about deregulation in seven service sectors is introduced, the privatization index becomes not significant, while the time varying measure of regulation is significant and positive. The issue here is whether the regulatory reforms for the service sector can be used for the economy as a whole.

\footnotetext{
${ }^{35}$ Note that the results for the effect of regulation on productivity in Nicoletti and Scarpetta (2003) subsume and extend the ones in Scarpetta , Hemming, Tressel and Woo (2002).
} 
In another set of results, entry barriers and privatization are considered separately for the (aggregate) manufacturing sector and the (aggregate).The time varying measure of entry liberalization in manufacturing is based only on data on trade liberalization, while the one for the service sector is the summary measure of liberalization in the seven service industries. In that case, basically no significant direct or indirect effect can be detected. Only when liberalization in manufacturing is redefined as the average of trade liberalization and entry liberalization in non manufacturing, one observes a significant direct positive effect of deregulation on TFP growth.

Finally, in the last set of results the 1998 time invariant sector specific OECD measures of liberalization are used together with time varying measures of entry liberalization for manufacturing and service industries (the former calculated again as the average of trade liberalization and entry liberalization in non manufacturing). The equations contain country, industry, and year dummies. The results suggest that entry liberalization in services has a positive effect on productivity growth. The only significant interaction is the one between entry liberalization in manufacturing and the technology gap. Privatization continues to have a positive direct effect on productivity growth.

Summarizing, there seems to be some evidence of a positive effect of privatization and entry liberalization on TFP growth. There is also evidence that entry barriers in manufacturing may affect the pace of technology absorption, especially for countries that lie away from the world frontier.

Additional evidence on the effect of regulation on per-capita GDP growth for industrial countries is contained in chapter III of the IMF World Economic Outlook 
(2004), while Loayza, Oviedo, and Serven (2004) is one of the very few papers that looks at the effect of regulation on the economic performance of a wide set of countries, including developing countries. The IMF study concentrates on fifteen developed countries with a maximum of five observations on growth rates calculated over three-year averages. The estimated equation contains standard controls for cross-country growth regressions and a menu of structural policy indicators, including (present and lagged) values of the time varying average product market regulation indicator developed by the OECD for seven non-manufacturing sectors, and average effective tax rates. The sample size is therefore small and the product market regulation indicator captures only a subset of the economy. The model is estimated by GMM dynamic panel data methods and suggests that both product market reform and trade reform have a positive and significant effect on growth, although it may take time for the full effects to be realized.

The main challenge when dealing with developing countries is the availability of detailed indices of product market regulation that reflect the cross sectional and time variability of product market regulation, although some of them, such as tariff barriers, are available at annual frequency and the indices of the Fraser Institute at five year intervals for many countries. The Loayza et al (2004) paper focuses on time invariant indices constructed from information from the World Bank, the Heritage Foundation, and the Fraser Institute and are meant to capture the fiscal burden, and product market regulation, the latter a composite of entry, trade, financial markets, bankruptcy, and contract enforcement indices. An index of labour market regulation is also constructed. 
The indices are used as regressors in standard cross sectional average growth regressions for output per capita over the 1990's, allowing their effect to depend on an index of the quality of governance. Their effect on output volatility is also considered. The inability to control for country specific unobserved effects and the time invariant nature of the indices over a period that witnessed substantial change is the main limit of the exercise. The effort made by the authors to instrument for regulation itself and the fact that they allow for an interaction with the quality of governance are two attractive features, together with the focus on a sample including developing countries. ${ }^{36}$

The results suggest a negative and significant direct effect of product (and labour) market regulation on growth, but the coefficient of the interaction with governance is significant (except for the fiscal burden index), and its sign suggests that better governance reduces the negative effect of regulation. Actually, the size of the coefficients are such that the overall effect of regulation is sizeable and negative for most developing countries, while it is zero or even mildly positive for countries with quality of governance similar to the US and the UK (and presumably other OECD countries). The results for macroeconomic volatility are similar: regulation increases volatility, but the effect is attenuated by good governance.

Note that the these results of on the interaction with governance, which imply that only in countries with low level of governance there is a large, significant and negative effect of regulation on productivity, contrast with the results, reviewed previously, that support a positive effect of product market reform on growth for industrial countries, insofar as the latter are likely to be characterized by better governance.

\footnotetext{
${ }^{36}$ Legal origin, fraction of the population that speaks a major European language and initial per capita GDP are used as instruments. The test of over-identifying restrictions does not suggest misspecification. Concerns about the power of such test, however, should not be forgotten.
} 
Gorgens, Paldman and Wurtz (2005) also investigate whether there are significant non-linearities in the effect of regulation on the growth of GDP per capita, depending upon the level of income. They use a panel of a hundred and twenty three countries for the period 1970-2000, divided in seven five years non overlapping periods and estimate by system-GMM of a growth equation specified as a third order Taylor series expansion in lagged values of income and of the Fraser Institute Economic Freedom Index. Results suggest that the effect of regulation is very different depending upon the level of income. For low income countries, regulation has no effect on growth. For middle income countries there is a negative effect of regulation for low values of regulation. For high values of regulation, there is no effect. For high income countries the effect is monotonic: less regulation generates more growth.

Let us focus now on the results for productivity growth in developed countries obtained by Griffith and Harrison (2004), using their two steps approach where the intermediate link is the mark-up. When the level or the growth rate of labour or total factor productivity in the business sector is regressed on the mark-up (the latter instrumented by the regulatory variables) they tend to find a positive and significant effect of the mark-up on both the level and growth rate of productivity. The conclusion that a higher mark-up has a mostly positive effect on productivity is not altered by allowing for non linear effects of the mark-up or by the direct inclusion of some regulation indices in the regression. Taken at face value, these results are consistent with the idea that monopoly rents provide the crucial incentive for productivity enhancing innovative activity. An alternative explanation is that the new jobs created by deregulation are in lower productivity sectors. An alternative explanation is that the time 
period available for estimation does not allow one to capture the complexity of the relationship between mark-up and productivity. For instance, the new firms that enter following a reduction in regulation may be initially less productive than incumbent surviving firms and it may take time for them to achieve higher levels of productivity. It is interesting to note that the positive relationship comes from the within variation in the data. If one does not include country dummies in the regression, allowing the between variation to play a role as well, the relationship between mark-up and productivity tends to become negative and significant.

Cincera and Galgau (2005) present results on the effect of entry and exit on output growth and labour productivity growth instrumented with regulation and other variables. Note that the coefficient of entry does not capture only the direct effect of entry on productivity, but also the indirect effect that entry has on the productivity of existing firms. There is some evidence at the $10 \%$ level that entry has a positive effect on labour productivity growth, while exit has a significant positive effect on it at the $5 \%$ level.

Loayza et al (2005), use a similar two steps approach to explain labour productivity growth in manufacturing for their subset of developed and developing countries, using turnover (divided by the standard deviation of terms of trade growth) as the intermediate variable. Standardized turnover is interacted with the average US turnover and it is instrumented by product market regulation, labour regulation, and fiscal burden. Average GDP per capita, the average growth rate of the terms of trade, and the output gap over the period are included as controls. Although the regulation variables are time invariant, so that the authors cannot control for unobserved heterogeneity, an interesting twist in their contribution is the decomposition of productivity growth into the 
"within" component, the "between" component and a component representing the portion of productivity growth due to entry and exit. A specification in which each regulatory variable is included directly in the productivity equations is also estimated by OLS. The overall results suggest that the portion of turnover explained by business regulation flexibility has a positive and significant effect on overall labour productivity growth. However, the only component that is significantly affected is its net entry component. In general there is little systematic evidence on how regulatory changes in the product market affect different components of productivity growth and hence on the channels through which regulatory reform may have enhanced aggregate productivity. This is obviously due to the necessity to have access to comprehensive firm level data to distinguish between a within, between and entry/exit component. There is some evidence, however, on the effect of regulation on the component of aggregate productivity levels Arnold, Nicoletti and Scarpetta (2008), show for European countries that indices of product market regulation are significantly inversely related with a measure of allocative efficiency based on the relative importance of the cross term in the Olley and Pakes decomposition of the level of TFP, calculated at the country, sector year level using the firm level Amadeus data set. ${ }^{37}$ This is particularly true for ICT using sectors.

Moreover, Haltiwanger and Krizan (2005), using the Investment Climate Assessment data set for developing and transition countries, show that an adverse business climate has a negative effect both on firm level average firm productivity (TFP) and on allocative efficiency, measured as the cross product between percentage deviation of firm market shares from average market shares in the country and the deviation of firm level productivity from average firm level productivity. The composite business climate

\footnotetext{
${ }^{37}$ Remember that the cross term reflects the extent to which more efficient firms have greater market shares.
} 
variable used as a regressor includes firm level information about the time spent dealing with government regulation, the time it takes to get a telephone installed, bribes as a percentage of annual sales, and the perception about property rights and the legal system and about labour market regulation as an obstacle to economic activity. The results hold also when the business climate perception variable is instrumented with country, size and age and for most of the individual components of the business climate index. ${ }^{38}$

In summary, most of the studies that include measures of regulation directly in the regression (alone or interacted) tend to find a negative effect of tighter regulation on total factor productivity or per capita output growth. These papers provide the more convincing support to the proposition that deregulation has a positive effect on productivity growth. However, studies that use the mark-up as the channel of transmission find that decreases in the mark-up associated with deregulation are associated with lower productivity growth (or level). ${ }^{39}$ Controlling for the mark-up, there is no evidence of an additional positive direct effect of deregulation on productivity (sometimes the opposite is the case). The cross-sectional dimension of the data suggests that countries with higher mark-ups have lower productivity growth rates, but one has to be aware that in this case we are not controlling for other country effects besides their competitive environment. On balance, relying on turnover or entry as the variable through which the effect of deregulation is transmitted suggests a positive effect of lowering regulatory burdens on overall productivity growth.

\footnotetext{
${ }^{38}$ See also Galindo Schiantarelli and Weiss (2000) for micro evidence on the impact of financial reform on the efficiency of allocation of investment funds and Banerjee and Duflo (2005) for a general review of the causes and empirical evidence on resource misallocation

${ }^{39}$ Note that higher mark-ups are associated also with more R\&D spending.
} 
The general conclusion that can be drawn at this point is that most, but not all, the evidence points towards a positive effect of less stringent regulation on productivity growth. There is also evidence of non linearities in the effect of product market regulation on productivity growth, with the effect of deregulation being larger in more developed countries. On the other hand better governance seems to mitigate the negative effects of regulation. Finally it would be premature to draw definitive conclusions in this respect. More work is also needed in order to understand how the effect of product market regulation on productivity growth is distributed between the within, between and entry/exit components or how it affects measures of allocative efficiency based on the Olley-Pakes decomposition of aggregate productivity levels.

\section{Summary and Conclusions}

What are the overall lessons that can be derived from this review of the available cross-country evidence on the effect of product market regulation? We have certainly learned a lot from the recent econometric work in this area, but there is still ambiguity on some of the issues.

There is considerable evidence that product market regulation that raises barriers to entry contributes to higher mark-ups. Moreover, the results support the conclusion that regulatory barriers in the product market have a negative effect on firm entry or turnover and are likely to slow the process of reallocation of resources.

As far as factor accumulation is concerned the direct evidence and the indirect one via effects on the mark-up suggest a positive effect of product market deregulation on 
investment and employment. The result for investment is particularly important because often new processes are embodied in new capital goods and find their way into the economic systems through the investment process. The evidence tends to be stronger for the service sector, while for manufacturing there is no evidence of a positive (or for that matter, negative) effect, although that may be the result of lack of adequate sector specific and time varying measures of regulation. Entry does not seem to be a key channel through which changes in regulation affect the demand for labour and capital, although there is clear evidence that entry responds strongly to the regulatory climate. The effect of entry on the reallocation of factors of production requires additional investigation.

The cross-country studies are not supportive, at this stage, of a strong positive effect of less stringent regulation on direct input measures of firms' innovative activities. Actually, the studies that use the mark-up as the transmission mechanism find that lower mark-ups discourage innovation. However, this result is sensitive to the choice of the sample of countries used in estimation. There is, instead, some evidence that non-tariff barriers have a negative effect on $\mathrm{R} \& \mathrm{D}$. The results based on the mark-up are at odds with some recent micro evidence for individual countries on the existence of an inverted U shaped relationship between the mark-up and firms' innovative activities. Clearly, more work is needed to resolve the theoretical ambiguities concerning the effect of product market regulation on firms' innovative activity and to come to more definitive conclusions on this issue. Progress in this area depends upon the availability of crosscountry data on firm's innovative activities that go beyond R\&D spending, such as patent counts, measures of firm's innovative investment, survey measures on the introduction of 
innovations, etc. It also requires a deeper understanding of how the nature of a country's industrial structure, the distance of a country from the technological frontier, the availability of human capital, and other initial conditions may lead to different results.

Finally, most of the studies that include measures of regulation directly in the regression (alone or interacted) tend to find a negative effect of tighter regulation on total factor productivity or per capita output growth. This cross-country evidence is consistent with the micro-econometric evidence that finds a positive and significant association between competition and productivity growth. These results are not confirmed by studies that use the mark-up as the channel of transmission, since in that case a decreases in the mark-up following deregulation is associated with lower productivity growth (or level). Relying on entry or turnover as the variable through which the effect of deregulation is transmitted suggests a positive effect of lowering regulatory burdens on overall productivity growth, but more work is needed in order to understand exactly how that is distributed between the within, between and entry/exit components. The general conclusion that can be drawn at this point is that most, although not all, the evidence points towards a positive effect of less stringent regulation on productivity growth.

This result is very important on its own, but also has an interesting consequence on a macro variable that has not been the focus of our survey, namely inflation. The faster rate of productivity growth associated with less stringent product market regulation reduces, ceteris paribus, inflationary pressure. In addition, if we consider the evidence that lower regulatory barriers lead to a smaller mark-up, it follows that regulatory reform 
may have favourable effects on inflation at short as well as longer horizons. Further systematic evidence on this issue would be very useful. ${ }^{40}$

An area in which further work is needed is the interaction between product market deregulation with the initial income level of income, the level of labour market regulation, the degree of financial development and the general quality of governance in a country. Product market deregulation has been introduced in countries at different levels of development and with different institutions. Moreover many countries have introduced reforms that affect not only the output market, but also the labour market and the financial sector. In the paper we have discussed some evidence of non linearities and interesting interactions of product market regulation with labour market regulation and governance. There is evidence that the effect of product market deregulation on productivity growth is larger in more developed countries. On the other hand, there is also some evidence that better governance seems to mitigate the negative effects of regulation. Finally some studies suggest that the positive employment effect of product market deregulation are stronger in countries with more regulated labour markets, but that product market deregulation may help in deregulating the labour market. However, more work is needed to come to definitive conclusions about how the effect of product market reform depends upon initial conditions and whether there are synergies in reform.

\footnotetext{
${ }^{40}$ See Neiss (2001) for cross sectional evidence on the relationship between the mark-up and inflation in OECD countries and Cavelaars (2002) for an cross sectional analysis of the effect of product market regulation.
} 


\section{References}

Aghion, P, R. Blundell, R. Griffith, P. Howitt, and S. Prantl (2005), "Entry, innovation and growth: Theory and evidence from UK firm-level data”, mimeo, Harvard University-UCL.

Aghion, P. N. Bloom, R. Blundell, R. Griffith, and P. Howitt (2005) “Competition and innovation: An inverted U relationship”, Quarterly Journal of Economics, May, 701-728.

Aghion, P. and R. Griffith (2005) Competition and Growth; Reconciling Theory and Evidence, The MIT Press, Cambridge, MA.

Aghion, P, R. Burgess, S. Redding, and F. Zilibotti (2003), "On the unequal effects of Liberalization: Theory and evidence from Indian de-licensing data”, mimeo, LSE_Harvard-IIES.

Aghion, P., C. Harris, P. Howitt, and J. Vickers (2001), "Competition, imitation and growth with step-by-step innovation”, Review of Economic Studies, 68, 467-492.

Aghion, P., M. Dewatripoint, and P. Rey (1997) “Corporate governance, competition policy and industrial policy” European Economic Review, 34, 322-329.

Aghion, P., C. Harris, and J. Vickers (1997), “Competition and growth with step-by-step innovation: An example”, European Economic review, Papers and Proceedings, 771-782.

Aghion, P., and P. Howitt (1992) “A Model of growth through creative destruction" Econometrica, 60, 323-351.

Alesina, A., S. Ardagna, G. Nicoletti, and F. Schiantarelli (2005), ”Regulation and investment”, Journal of the European Economic Association, June, 1-35.

Ahn, S. (2002), "Competition, innovation and productivity growth: A review of theory and evidence”, OECD, Economics Department, Working Paper 317.

Ahn, S. (2001), "Firm Dynamics and productivity growth: A review of micro evidence from OECD countries,”, OECD, Economics Department Working Paper 297.

Amable, B., Demmou, and L. Gatti (2007), "Employment performance and institutions: New answers to an old question”, IZA Discussion Paper No. 2731.

Arnold, J., G. Nicoletti, and S. Scarpetta (2008), "Regulation, allocative efficiency and productivity in OECD Countries: Industry and firm level evidence”, OECD Economics Department Working Paper no. 616.

Arnold, J., B. Javorcik, M. Lipscomb, and A. Mattoo (2008), "Services reform and manufacturing performance: Evidence from India”, mimeo, OECD.

Baily, M.N., C. Hulten, and D. Campbell (1992), "Productivity dynamics in manufacturing plants”, Brookings Papers on Economic Activity: Microeconomics, 187-249. 
Banerjee, A and E. Duflo (2005), "Growth theory through the lens of development economics", Ch. 7 in the Handbook of Economic Growth. Vol.1A, P. Aghion and S. Durlauf, eds., North Holland.

Bartelsman, E., J. Haltiwanger, and S. Scarpetta (2004), "Microeconomic evidence of creative destruction in industrial and developing countries", World Development Report background paper, the World Bank.

Bassanini, A., and E. Ernst (2002), "Labor market institutions, product market regulation, and innovation: Cross-country evidence”, OECD Economics Department Working Paper (2002)2.

Bassanini A., and R. Duval (2006), "Employment patterns in OECD countries: Reassessing the role of policies and institutions", OECD Economics Department Working papers, No. 486.

Basu, S. and M. Kimball (1997), "Cyclical productivity with unobserved input variation”, NBER Working Paper 5915.

Bartelsman, E.J., J. Haltiwanger, S. Scarpetta (2004), "Microeconomic evidence of creative destruction in industrial and developing countries", Tinbergen Institute Discussion Paper, TI 20004-114/3

Berger H. and S. Danninger (2006), "The employment effects of labor and product market deregulation and their implications for structural reforms", CESifo Working paper No. 1709.

Bergoeing, R., N. Loayza, and A. Repetto (2004), "Slow recoveries", Journal of Development Economics, 75, 473-506.

Bernard, A.B., J. Eaton, J.B. Jensen, and S. Kortum (2003), “ Plants and productivity in International Trade”, American Economic Review, 93(4), 1268-1290.

Blanchard, O., and F. Giavazzi (2003) "Macroeconomic effects of regulation and deregulation in goods and labor markets" Quarterly Journal of Economics, 118, 1369-1413.

Blundell, R., R. Griffith and J. Van Reenen (1999) "Market share, market value and innovation in a panel of British manufacturing firms" Review of Economic Studies, (1999) 66, 529-554.

Bottasso, A., and Sembenelli, A. (2001) "Market power, productivity, and the EU Single Market Program: Evidence from a panel of Italian firms”, European Economic Review, 45(1), 167-186.

Brandt, N. (2004), "Business dynamics, regulation and performance", OECD, Directorate for Science Technology and Industry Working paper 2004/3.

Caballero, R., and M. Hammour (1998), “ The Macroeconomics of specificity”, Journal of Political Economy, Vol. 106, pp. 724-767.

Caballero, R. and M. Hammour (1996), "On the timing and efficiency of creative destruction”, Quarterly Journal of Economics, 111(3), 805-852. 
Caballero, R., and M. Hammour (1994), “The cleansing effects of recessions”, American Economic Review”, 84(5), 1356-1368.

Card, D, and R. Freeman (2004), "What have two decades of British economic reform delivered”, NBER Working Paper 8801.

Cavelaars, P. (2002), "Does competition enhancement have permanent inflation effects?”, DNB Staff Reports no. 92/2002.

Cincera, M., and O. Galgau (2005), "Impact of market entry and exit on EU productivity and growth performance", European Economy, European Commission, Directorate General Economic and Financial Affairs, Economic Papers N. 222, February.

Cohen W.M., and R. Levin (1989), "Empirical studies of innovation and market structure", in R. Schmalensee and R.D. Willig (eds.) Handbook of Industrial Organization, Vol. II, North Holland, Amsterdam.

Conway, P., J. Janod and G. Nicoletti (2005), "Product market regulation in OECD countries: 1998 to 22003”, OECD Economics Department Working Papers, No. 419.

Conway, P. and G. Nicoletti (2006), "Product market regulation in the nonmanufacturing sectors of OECD countries", OECD Economics Department Working Papers, No. 530.

Crafts, N. (2006), "Regulation and productivity performance", Oxford Review of Economic Policy, 22(2), 186-201.

Djankov, S., R.La Porta, F. Lopes de Silanes, and A. Shleifer (2000) "The regulation of entry”, Quarterly Journal of Economics, February 2002, 1-37.

Disney, R., J. Haskel, and Y. Heden (2000), "Restructuring and productivity growth in UK manufacturing”, CEPR Discussion Paper. 2463, May.

Eslava, M., J. Haltiwanger, A. Kugler, and M. Kugler (2005), "Employment and capital adjustment after factor market deregulation: Panel evidence from Columbian plants”, World Bank, mimeo.

Faini, R., J. Haskel, G.Barba Navaretti ,C.Scarpa, and C. Wey (2005), “Contrasting Europe's decline: Do product market reforms help?”, mimeo.

Fiori, G., G. Nicoletti, and S. Scarpetta (2007), "Employment outcomes and the interaction between product and labor market deregulation: Are they substitutes or complements?” Boston College, Department of Economics Working Paper 663.

Fraser Institute (2002) Economic Freedom of the World: 2002 Annual Report,

Foster, L. J. Haltiwanger, and C.J. Krizan (2001), “Aggregate productivity growth: Lessons from microeconomic evidence" in E. Dean, M. Harper, and C. Hulten, eds., New Developments in Productivity Analysis, Chicago, University of Chicago Press.

Galindo, A., F. Schiantarelli, and A. Weiss, "Does financial reform improve the allocation of investment? Micro evidence from developing countries", Journal of Development Economics, 83, pp. 562-587, 2007. 
Grilliches, Z., and H. Regev (1995), "Firm productivity in Israeli industry: 1979-1988”, Journal of Econometrics, 65, 175-203.

Gagnepain P., and P.L Marin Uribe (2003) "Competition and efficiency in European aviation” ,Universidad Carlos III de Madrid, mimeo.

Geroski, P. (1995) Market Structure, Corporate Performance and Innovative Activity, Oxford: Oxford University Press.

Goldberg, P., and Verboven, F. (2001) "Market integration and convergence of the Law of One Price: Evidence from the European car market” NER Working Paper 8575.

Gorgens, T., M. Paldam, and A. Wurtz (2005), "Growth, income and regulation: A nonlinear approach”, University of Copenhagen, CAM Working Paper 2005-12.

Green, R., and J Haskel (2003) "Seeking a premier league economy: The role of privatisations" Seeking a Premier League Economy, R. Blundell, D. Card, R. Freeman (eds.), University of Chicago Press: Chicago.

Griffith, R., and R. Harrison (2004), "The link between product market reform and macro-economic performance" European Economy, European Commission, Directorate-General for Economic and Financial Affairs, Economic Papers N. 209, August.

Griffith, R., S. Redding, and J. Van Reenen (2004) "Mapping the two faces of R\&D: Productivity growth in a panel of OECD manufacturing industries", Review of Economics and Statistics, 86(4), November, 883-895.

Griffith R., S. Redding, and J. Van Reenen (2003) "R\&D and absorptive capacity: from theory to evidence" Scandinavian Journal of Economics, 105(1), 99-118.

Griffith, R., R. Harrison and G. Mccartney (2007), "Product market reforms, labour market institutions and unemployment”, The Economic Journal, 117(519), March, c142-C166(1).

Grossman G.M., and E. Helpman (1991) "Quality ladders in the theory of growth" Review of Economic Studies Vol. 58, Issue 1, 43-61.

Hall, R.E. (1986), "Market structure and macroeconomic fluctuations”, Brookings Papers on Economic Activity, 2, 285-322.

Hall, R.E. (1988), "The relation between price and marginal cost in US industry", Journal of Political Economy, 96(5), 921-947.

Haltiwanger, J. (2000), "Aggregate growth: What have we learned from microeconomic evidence?”, OECD, Economics Department Working Paper 7741.

Haltiwanger and Schweiger (2005), "Allocative efficiency and the business climate", University of Maryland, mimeo.

Harrison A.E. (1994) " Productivity, imperfect competition and trade reform: Theory and evidence”, Journal of International Economics, 36, 53-73.

Harrison, A, and A. Revenga, (1995) "The effects of trade policy reform: what do we really know?” NBER Working Paper 5225. 
Hart, O. (1983) "The market mechanism as an incentive scheme," Bell Journal of Economics, 14 (Autumn 1983), 366-382.

Heckman,J., and C. Pages (2003), "Law and Employment: Lessons from Latin America and the Caribbean”, NBER Working Paper 10129.

Holmstrom, B. (1982), "Managerial incentive problems - A dynamic perspective”, in Essays in Economics and Management in Honour of Lars Wahlbeck, Swedish School of Economics.

Howell, D.R., D. Baker, A. Glyn, J. Schmitt (20070, "Are protective labor market institutions at the root of unemployment? A critical review of the evidence", Capitalism and Society, 2(1), 1-71.

.Hsieh, C.T., and P. Klenow,(2006) "Misallocation and manufacturing TFP in China and India”, University of California at Berkeley, mimeo.

International Monetary Fund, World Economic Outlook (2004), Ch. III "Fostering structural reforms in industrial countries”, International, Monetary Fund, April, 103-146.

Jagannathan, R., and S. Srinivasan (2000) "Does product market competition reduce agency costs?”, NBER Working Paper 7480, January.

Jones, C (1999), “Growth with or without scale effects?” American Economic Review Papers and Proceedings, May, Vol. 89, pp. 139-144.

Klapper, L. L. Laeven, and R.G. Rajan (2004), "Business environment and firm entry: Evidence from international data” NBER Working Paper 10380.

Klette, T.J. (1999), "Market power, scale economies and productivity: estimates from a panel of establishment data”, Journal of Industrial Economics, 47(4) 451-476.

Koedijk, K., and J. Kremers (1996), "Deregulation: A political economy analysis", Economic Policy, October, 445-467.

Levinsohn, J. (1993), “Testing the imports as market discipline hypothesis”, Journal of International Economics, 35, 1-22.

Loayza N.V., A.M. Oviedo, and L. Serven (2004), "Regulation and macroeconomic performance”, World Bank, September, mimeo.

Loayza N.V., A.M. Oviedo, and L. Serven (2005), "Regulation and microeconomic dynamics: A comparative assessment for Latin America”, World Bank, mimeo.

Martins, J, S. Scarpetta, and D. Pilat (1996) "Mark-up ratios in manufacturing industries: estimates for 14 OECD countries”, OECD Working Paper 162.

Melitz, M. (2003) "The impact of trade on intra-industry reallocations and aggregate industry productivity”, Econometrica, 71(6), November, 1695-1725.

Melitz, M. and S. Polanec (2008), "Dynamic Olley-Pakes decomposition with entry and exit”, Princeton University, mimeo.

Mookherjee, D. (1984), "Optimal incentive schemes with many agents", Review of Economic Studies, 51, July, 433-446. 
Moulton, B.R. (1990), "An illustration of the pitfall in estimating the effects of aggregate variables on micro units”, Review of Economics and Statistics, 72(2), 334-338.

Nalebuff, B., and J. Stiglitz (1983), “Information, competition and markets”, American Economic Review, 73, 278-283.

Neiss, K.S. (2001), “The markup and inflation: Evidence in OECD countries”, Canadian Journal of Economics, 34(2), 570-587.

Nickell, S. (1996) "Competition and corporate performance", Journal of Political Economy, 104, 724-746.

Nickell, S., D. Nicolitsas, and N. Dryden (1997), “What makes firms perform well?”, European economic Review, 41, 725-796.

Nickell, S., L. Nunziata, and W. Ochel (2005), "Unemployment in the OECD since the 1960’s: What do we know?”, The Economic Journal, 115(500), January, 1-27.

Nicoletti, G. and F. Pryor (2006), "Subjective and objective measures of governmental regulations in OECD nations”, Journal of Economic Behaviour and Organization, 59(3), 433-449.

Nicoletti, G., and S. Scarpetta (2003) "Regulation, productivity and growth: OECD evidence”, Economic Policy, 18(36), 11-72.

Nicoletti, G., S. Scarpetta, and O. Boylaud (1999), "Summary indicators of product market regulation with an extension to employment protection leislation”, OECD Economics Department Working Papers, No. 226.

Olley, G.S., and A. Pakes (1996) "The dynamics of productivity in the telecommunications equipment industry” Econometrica, 64:6, 1263-1297.

Parente, S. and E. Prescott (1994), "Barriers to technology adoption and development”, Journal of Political Economy, 102(2), 298-321.

Pavcnik, N. (2002) “Trade liberalization, exit and productivity improvements: evidence from Chilean plants” Review of Economic Studies, 69, 245-276.

Rodriguez, F., and D. Rodrik (2001), “Trade policy and economic growth; A skeptic's guide to the cross-national evidence”, Mcroeconomics Annual 2000, B. Bernanke, and K.S. Rogoff, eds, MIT Press for NBER, Cambridge, MA.

Restuccia, D. and R. Rogerson (2003), "Policy distortions and aggregate productivity with heterogeneous plants”, University of Toronto, mimeo.

Romer, P. (1990) “Endogenous technical change” Journal of Political Economy Vol. 98, Issue 5, Part 2: The Problem of Development, S71-S102.

Scarpetta, S. P. Hemmings, T. Tressel, and J. Woo, (2002) "The role of policy and institutions for productivity and firm dynamics: Evidence from micro and industry data” OECD Economics Department Working Paper (2002)15.

Scharfstein, D. (1988), "Product market competition and managerial slack”, Rand Journal of Economics, Spring, 147-155. 
Schmidt, K. (1997) "Managerial Incentives and Product Market Competition" Review of Economic Studies Vol. 64, Issue 2, 191-213.

Schumpeter, J.A. (1942), Capitalism, Socialism and Democracy, New York, Harper and Brothers.

Srivastava, V. (1996), Liberalization, Productivity and Competition, Oxford University Press, Delhi.

Vamvakidis, A. (2002), "How robust is the growth-openness connection? Historical evidence”, Journal of Economic Growth, 7(1), March, 57-80.

Wooldridge, J.M. (2003), "Cluster-sample methods in applied econometrics", American economic Review, papers and Proceedings, 93(2), 133-138.

World Bank, "Doing Business Database”, available at http://www.doingbusiness.org.

Yanikkaya, H. (2003), “Trade openness and economic growth: A cross-country empirical investigation”, Journal of Development Economics, 72, October, 57-89. 